\title{
Perception on Management of Nursing Education Institutes among Bachelors Students in Selected Nursing Colleges at Kathmandu
}

\author{
Bhuwan Kumari Dangol ${ }^{1}$ and Narbada Thapa ${ }^{2}$
}

${ }^{1} \mathrm{PhD}$ Scholar, Mewar University, Rajasthan, India

${ }^{2}$ Professor, Tribhuvan University, Kirtipur, Nepal

\section{Corresponding Author}

Bhuwan Kumari Dangol

Email: bhuwandangol@gmail.com

\section{ABSTRACT}

Management is a process of planning, decision making, organizing, leading, motivating and controlling, and an effective utilization of the resources to reach the organizational goals efficiently and effectively. Management has a crucial role in quality of work and production in any institutions. Although a rapid increase of Nursing Education Institutions in Nepal since last decade which had been trained thousands of nursing cadres, the management aspects of these institutions are not studied adequately. Thus current study intended to explore the current status of Nursing Education Institution Management as experienced and perceived by the bachelors nursing students. A descriptive cross-sectional study was conducted among the nursing institutions in Kathmandu valley. Of the total 28 in the valley, 14 were selected purposively. From the selected institutions, all 377 eligible students currently in final year of study were selected. Among them, 208were from BSN and 169 were from B Sc program. The data was collected through the self administered structured questioners after taking informed consent. Data entry and analysis was done in SPSS version 16 software. The findings of the study show that $70 \%$ students were satisfied in institutional management (mean59.62, $\mathrm{SD} \pm 3.66)$. In academic management (78\%), (mean139.82, $\mathrm{SD} \pm 6.22$ ), followed by human resources $67 \%$, (mean43.54, $\mathrm{SD} \pm 2.79)$ and were in physical resources management 75\% students were satisfied (mean45.02, $\mathrm{SD} \pm 3.08$ ). Analysis of variations between group (administrators, faculties, students) found statistical significance ( $\mathrm{p}$ value $<0.05$ ). So it is concluded the perception of students, faculties and administrator were different on managing the nursing education.

\section{KEYWORDS}

Academic management, Human resource management, Institutional management, Nursing education, Physical resources management 


\section{INTRODUCTION}

Management is a key factor for the accomplishment of any organized activity, which is an essential for all organizations. It is a stimulating any institution it manages. Management refers to the series of functions that were planning, organization, decision making, leading and controlling. People of the organization may fulfill it (Huma, 2005).Management is art, as well as fast developing science. Through management inputs are fed to the end results in the form of goods, services and satisfaction. It is known as outcome. Management is a process that utilizes resources, to accomplish an organizational goal (Clement, 2016). In nursing education institute management is crucial to product the human workforce. Nursing is a profession. It applies the principles of scientific sound and technical expert to achieve effective care. The effective care is come from in nursing education. This is absolutely crucial for the delivery of safe and high excellence nursing care (Aziz, 2011). Among health care provider Nurses occupied the hugs portion. They involve $80 \%$ of direct patient care. Nursing is a basic essential to all human being in their every step of life. These skills, knowledge and attitude they learn from their training. Clinical learning is a foremost part of nursing education. So, nurses should provide the right education with skill to equip them for their future roles (Hanifi, 2012). These all skill, knowledge they learn from during their training period, in education institute. Nursing education emphasized on its professionalism that patient care as its top preference with respects the dignity and values of service user. So the nursing education institutes always concerns to meet them. These essential learning depends on the expert teachers\& supervision during clinical practices. The most successful learning experiences take place in practical experiences. It also helps to achieve through individual practices too. Therefore, management is essential to achieve the required competitive skills to meet globally demands (Hattingh, 2013). The roles of tomorrow's nurses will be even more challenging and specialized. They should be more assertive and need leadership capacity. Due to nursing practices at present is not only inside the hospital. Primary purpose of nursing education is to prepare the future nursing workforce. So the nurses should learn all kinds of knowledge, skills, and behaviors. The nursing education institutes should arrange to equip them for future demands (Report of the Wills, 2012). It is success, when the nursing education institutes manage effectively.

\section{METHOD}

A descriptive explorative research design was used to find out the effectiveness of management for nursing education. Data was obtained from bachelor level nursing students (BNS and B Sc) in their final year of study. This study was conducted in nursing education institutes located in Kathmandu valley. A non probability purposive sampling technique was used to select the institutions. A total of 14 Nursing institutions were selected they were three from Tribhuvan University, one from Kathmandu University, one from Pokhara University, eight from Purbanchal University and one from Health science academic and their constituent and affiliated colleges.

Vol. 7. No. I 
For the sample size 50\% were taken from bachelor level last year nursing students (BNS and B Sc). Data were collected from bachelor in nursing sciences (BNS) 208 and generic bachelor science in nursing (B Sc nursing) 169 using by self administrates structure questioners. During data collection written and verbal consent was obtain. On the day of data collection the questioners were distributed and the next day it was collected and checked for the completeness. Research instrument was developed by researcher herself on reference of Nepal nursing council basic minimum requirement criteria and extensive literature review of basic criteria of management required for nursing institutes. The research instrument had included major two parts. Part one background information of the respondents included four question and second part perceptions on management of nursing institutes in liker scale. It included 81 indicators. Each scale divided 5 points, strongly agree (5), agree (4), undecided (3), disagree (2) and strongly disagree (1). The minimum score is 81 and the maximum score is 405 . Before data collection permission was taken from university and the nursing education institutions by verbal as well as written. Ethical approval was obtained from National Health research council. Written and verbal consent was taken from each respondent. Data was analyzed by using SPSS version 16 software. The findings were described in descriptive and inferential statistics.

\section{RESULT}

Table 1: Background Characteristics of Respondents

\begin{tabular}{lcc} 
& & $\mathrm{n}=37$ \\
\hline Characteristics & Number & Percent \\
\hline Bachelor in Nursing science(BNS) & 208 & 55.2 \\
B Sc Nursing & 169 & 44.7 \\
District & & \\
Kathmandu & 298 & 79 \\
Lalitpur & 79 & 21 \\
\hline
\end{tabular}

Above Table 1 shows that more than half (55.2\%) students were bachelors in nursing science and majority were (79\%) from Kathmandu district. 
Table 2: Students' Perception on Institutional management

\begin{tabular}{|c|c|c|c|c|c|c|c|c|c|c|}
\hline \multirow[t]{2}{*}{ Statement } & \multicolumn{2}{|c|}{$\begin{array}{l}\text { Strongly } \\
\text { agree }\end{array}$} & \multicolumn{2}{|c|}{ Agree } & \multicolumn{2}{|c|}{ Undecided } & \multicolumn{2}{|c|}{ Disagree } & \multicolumn{2}{|c|}{$\begin{array}{l}\text { Strongly } \\
\text { disagree }\end{array}$} \\
\hline & $\mathrm{N}$ & $\%$ & $\mathrm{~N}$ & $\%$ & $\mathrm{~N}$ & $\%$ & $\mathrm{~N}$ & $\%$ & $\mathrm{~N}$ & $\%$ \\
\hline Goal of NEI is clearly stated & 1 & 0.3 & 355 & 94.2 & 18 & 4.8 & 3 & 0.8 & 0 & 0 \\
\hline $\begin{array}{l}\text { Staffs understood the vision, } \\
\text { mission and objective of NEI }\end{array}$ & 1 & 0.3 & 332 & 88.1 & 30 & 8 & 14 & 3.64 & 0 & 0 \\
\hline $\begin{array}{l}\text { Organizational structure is } \\
\text { clearly written and displayed }\end{array}$ & 77 & 20.4 & 285 & 75.6 & 2 & 0.5 & 13 & 3.4 & 0 & 0 \\
\hline Strategic plan is clearly stated & 1 & 0.3 & 2.8 & 55.2 & 131 & 34.7 & 36 & 9.5 & 1 & 0.3 \\
\hline $\begin{array}{l}\text { Executive committee is well } \\
\text { functioning }\end{array}$ & 0 & 0 & 134 & 35.5 & 136 & 36.1 & 98 & 26 & 9 & 2.3 \\
\hline $\begin{array}{l}\text { Nurse leader Provide effective } \\
\text { leadership }\end{array}$ & 0 & 0 & 269 & 71.4 & 26 & 6.9 & 77 & 20.4 & 5 & 1.3 \\
\hline $\begin{array}{l}\text { NEI had separate financial, } \\
\text { personnel, examination section }\end{array}$ & 15 & 4 & 362 & 95.9 & 0 & 0 & 0 & 0 & 0 & 0 \\
\hline $\begin{array}{l}\text { Resources are sufficient to } \\
\text { operate institute }\end{array}$ & 5 & 1.3 & 176 & 46.7 & 45 & 11.9 & 151 & 40.1 & 0 & 0 \\
\hline $\begin{array}{l}\text { The quality assurance system is } \\
\text { used in institute }\end{array}$ & 0 & 0 & 0 & 0 & 346 & 91.8 & 30 & 8 & 1 & 0.3 \\
\hline
\end{tabular}

$\mathrm{NEI}=$ Nursing education institute

All most all (94.2\%) students were agreed on the goal of nursing education institute clearly stated, and $88.1 \%$, and $75.6 \%$ agreed on all staffs understood the organization vision, mission and objectives of the organization and organizational structure is clearly written and displayed, respectively (Table 2). Thirty six percent of the students were undecided on executive committee is functioning. Most of the students (71.4\%) were agreed on nurse leader provide effective leadership and all most all (95.9\%) students agreed the existence of a separate administration, finance and examination section in NEI. Only $46.7 \%$ students were agreed on resource sufficient to operate the institute. All most all students were undecided on quality assurance system used in institute. 
ISSN: 2362-1303 (Paper) | eISSN: 2362-1311 (Online)

JOURNAL OF ADVANCED ACADEMIC RESEARCH (JAAR)

June 2020

Table 3: Students' perception on academic management

\begin{tabular}{|c|c|c|c|c|c|c|c|c|c|c|}
\hline \multirow[t]{2}{*}{ Statement } & \multicolumn{2}{|c|}{$\begin{array}{l}\text { Strongly } \\
\text { agree }\end{array}$} & \multicolumn{2}{|c|}{ Agree } & \multicolumn{2}{|c|}{ Undecided } & \multicolumn{2}{|c|}{ Disagree } & \multicolumn{2}{|c|}{$\begin{array}{l}\text { Strongly } \\
\text { disagree }\end{array}$} \\
\hline & $\mathrm{N}$ & $\%$ & $\mathrm{~N}$ & $\%$ & $\mathrm{~N}$ & $\%$ & $\mathrm{~N}$ & $\%$ & $\mathrm{~N}$ & $\%$ \\
\hline $\begin{array}{l}\text { Proper teacher students ratio for } \\
\text { theory and practical }\end{array}$ & 2 & 0.5 & 230 & 61 & 8 & 2.1 & 137 & $\begin{array}{c}36 . \\
3\end{array}$ & 0 & 0 \\
\hline $\begin{array}{l}\text { Theory and practical session } \\
\text { conduct on the basis of } \\
\text { operational plan }\end{array}$ & 0 & 0 & 320 & $\begin{array}{c}84 . \\
9\end{array}$ & 13 & 3.4 & 44 & $\begin{array}{c}11 . \\
7\end{array}$ & 0 & 0 \\
\hline Faculties are competent & 13 & 3.4 & 342 & $\begin{array}{c}90 . \\
7\end{array}$ & 8 & 2.1 & 14 & 3.7 & 0 & 0 \\
\hline $\begin{array}{l}\text { Ensure the integration of both } \\
\text { theory and practical in instruction } \\
\text { delivery }\end{array}$ & 4 & 1.1 & 342 & $\begin{array}{c}90 . \\
7\end{array}$ & 2 & 0.5 & 28 & 7.4 & 1 & 0.3 \\
\hline $\begin{array}{l}\text { Curriculum cover all aspect of } \\
\text { learning needs }\end{array}$ & 1 & 0.3 & 345 & $\begin{array}{c}91 . \\
5\end{array}$ & 26 & 6.9 & 5 & 1.3 & 0 & 0 \\
\hline $\begin{array}{l}\text { Student got effective supervision in } \\
\text { clinical practice }\end{array}$ & 5 & 1.3 & 263 & $\begin{array}{c}69 . \\
8\end{array}$ & 5 & 1.3 & 100 & $\begin{array}{c}26 . \\
5\end{array}$ & 4 & 1.1 \\
\hline $\begin{array}{l}\text { NEI have definite plan for student } \\
\text { intake }\end{array}$ & 5 & 1.3 & 370 & $\begin{array}{c}98 . \\
1\end{array}$ & 0 & 0 & 2 & 0.5 & 0 & 0 \\
\hline $\begin{array}{l}\text { Assure students' percentage of } \\
\text { attendance in theory and practical }\end{array}$ & 45 & $\begin{array}{c}11 . \\
9\end{array}$ & 331 & $\begin{array}{c}87 . \\
8\end{array}$ & 1 & 0.3 & 0 & 0 & 0 & 0 \\
\hline $\begin{array}{l}\text { Students achieve skill, knowledge } \\
\text { as curriculum indicated }\end{array}$ & 0 & 0 & 375 & $\begin{array}{c}99 . \\
0\end{array}$ & 2 & 0.5 & 0 & 0 & 0 & 0 \\
\hline $\begin{array}{l}\text { Applied evaluation policy provided } \\
\text { by authority (University) }\end{array}$ & 0 & 0 & 335 & $\begin{array}{c}88 . \\
9\end{array}$ & 10 & 2.7 & 32 & 8.5 & 0 & 0 \\
\hline $\begin{array}{l}\text { Students get enough opportunity to } \\
\text { learn }\end{array}$ & 20 & 5.3 & 346 & $\begin{array}{c}91 . \\
8\end{array}$ & 3 & 0.8 & 8 & 2.1 & 0 & 0 \\
\hline
\end{tabular}

More than half (61\%) of the students were agreed on the proper teacher students ratio for theory and practical and majority $(84.9 \%)$ of them were agreed in theory and practical session conduct on the basis of operational plan. All most all (90.7\% and 91.5\%) of student were agreed on faculties are competent, the Curriculum cover all aspect of learning needs, respectively. Seventy percent students were agreed proper clinical supervision. All most all $(98.1 \%)$ students were agreed definite plan for student intake and, 87.8\% and $99 \%$ agreed Assure students' attendance in theory and practical and achieve skill, knowledge as curriculum indicated, respectively. Majority 
ISSN: 2362-1303 (Paper) | eISSN: 2362-1311 (Online)

JOURNAL OF ADVANCED ACADEMIC RESEARCH (JAAR)

June 2020

of them (88.9\%) and $91,8 \%$ were agreed on used of evaluation policy assigned by university and they got enough learning opportunity respectively (Table 3).

Table 4: Students' perception on Human Resources Management

\begin{tabular}{|c|c|c|c|c|c|c|c|c|c|c|}
\hline \multirow[t]{2}{*}{ Statement } & \multicolumn{3}{|c|}{ Strongly agree } & Agree & \multicolumn{2}{|c|}{ Undecided } & \multicolumn{2}{|c|}{ Disagree } & \multicolumn{2}{|c|}{$\begin{array}{l}\text { Strongly } \\
\text { disagree }\end{array}$} \\
\hline & $\mathrm{N}$ & $\%$ & $\mathrm{~N}$ & $\%$ & $\mathrm{~N}$ & $\%$ & $\mathrm{~N}$ & $\%$ & $\mathrm{~N}$ & $\%$ \\
\hline $\begin{array}{l}\text { Written job description for } \\
\text { staffs }\end{array}$ & 14 & 3.7 & 295 & 78.2 & 41 & 10.9 & 26 & 6.9 & 1 & 0.3 \\
\hline $\begin{array}{l}\text { Nurse administrator has } \\
\text { definite authority and } \\
\text { accountability }\end{array}$ & 46 & 12.2 & 220 & 58.4 & 79 & 21 & 32 & 8.5 & 0 & 0 \\
\hline $\begin{array}{l}\text { Nurse administrator is recruited } \\
\text { from own organization }\end{array}$ & 20 & 5.3 & 189 & 76.7 & 38 & 10.1 & 30 & 8 & 0 & 0 \\
\hline $\begin{array}{l}\text { The decision making process by } \\
\text { participatory ways }\end{array}$ & 20 & 5.3 & 168 & 44.6 & 72 & 19.1 & 117 & 31 & 0 & 0 \\
\hline Staffs are dedicated & 2 & 0.5 & 327 & 86.7 & 41 & 10.9 & 7 & 1.9 & 0 & 0 \\
\hline $\begin{array}{l}\text { NEI had clear Staffs } \\
\text { recruitment policy }\end{array}$ & 6 & 1.6 & 153 & 40.6 & 119 & 31.6 & 94 & 24.9 & 5 & 1.3 \\
\hline $\begin{array}{l}\text { Personnel are evaluated } \\
\text { routinely }\end{array}$ & 6 & 1.6 & 177 & 46.9 & 144 & 38.2 & 50 & 13.3 & 0 & 0 \\
\hline
\end{tabular}

Above Table 4 show that majority of students $(78.2 \%)$ were agreed the staffs had written job description. More than half (58.4\%), and 76.7\% agreed nursing administrator had definite authority and accountability and they were promoted from own institute respectively. only $44.6 \%$, agreed in decision making process were participatory and $86.7 \%$ agreed the staff were dedicated respectively. Only $40.6 \%$ and $46.9 \%$ students were agreed that personnel were recruited through open competition and their performance appraisal were conducted annually respectively. 
Table 5: Students Perception on Physical Resources Management

\begin{tabular}{|c|c|c|c|c|c|c|c|c|c|c|}
\hline \multirow[t]{2}{*}{ Statement } & \multicolumn{2}{|c|}{$\begin{array}{l}\text { Strongly } \\
\text { agree }\end{array}$} & \multicolumn{2}{|c|}{ Agree } & \multicolumn{2}{|c|}{$\begin{array}{l}\text { Undecide } \\
\qquad \mathrm{d}\end{array}$} & \multicolumn{2}{|c|}{ Disagree } & \multicolumn{2}{|c|}{$\begin{array}{l}\text { Strongly } \\
\text { disagree }\end{array}$} \\
\hline & $\mathrm{N}$ & $\%$ & $\mathrm{~N}$ & $\%$ & $\mathrm{~N}$ & $\%$ & $\mathrm{~N}$ & $\%$ & $\mathrm{~N}$ & $\%$ \\
\hline $\begin{array}{l}\text { College building fulfills the } \\
\text { academic requirement }\end{array}$ & 10 & 2.7 & 366 & 97.1 & 0 & 0 & 1 & 0.3 & 0 & 0 \\
\hline $\begin{array}{l}\text { Class rooms are sufficient and } \\
\text { well equipped }\end{array}$ & 375 & $\begin{array}{r}99 . \\
5\end{array}$ & 1 & 0.3 & 1 & 0.3 & 0 & 0 & 0 & 0 \\
\hline $\begin{array}{l}\text { Skill laboratories are well } \\
\text { equipped and used }\end{array}$ & 0 & 0 & 258 & 68.4 & 7 & 1.9 & 112 & $\begin{array}{r}29 . \\
7\end{array}$ & 0 & 0 \\
\hline $\begin{array}{l}\text { Library can meet the students } \\
\text { learning needs }\end{array}$ & 0 & 0 & 330 & 87.5 & 0 & 0 & 46 & $\begin{array}{r}12 . \\
2\end{array}$ & 1 & 0.3 \\
\hline $\begin{array}{l}\text { Computer and internet facilities } \\
\text { are available for students and } \\
\text { staffs }\end{array}$ & 1 & 0.3 & 328 & 87 & 0 & 0 & 48 & $\begin{array}{r}12 . \\
7\end{array}$ & 0 & 0 \\
\hline $\begin{array}{l}\text { Transportation facility is } \\
\text { available for students }\end{array}$ & 0 & 0 & 281 & 74.5 & 5 & 1.3 & 91 & $\begin{array}{r}24 . \\
1\end{array}$ & 0 & 0 \\
\hline $\begin{array}{l}\text { NEI has own hospital for clinic } \\
\text { practices }\end{array}$ & 3 & 0.8 & 355 & 94.2 & 1 & 0.3 & 18 & 4.8 & 0 & 0 \\
\hline
\end{tabular}

The above Table 5 shows that all most all students ( $>90 \%)$ were agreed on collage building can fulfilled the academic requirement, class rooms are sufficient and well equipped and $68.4 \%$ were agreed in Skill laboratories are well equipped and can practiced sixty nine percent students agreed the skill laboratory are well equipped and they can use the laboratory. Majority (87.5\%) students agreed library fulfilled the student academic need, and $87 \%$ and $74.5 \%$ students were agreed NEI provide computer and internet and transportation facility, respectively. All most all students were agreed in Nursing Education Institutes had own general hospital for clinical practice.

\section{Vol. 7. No. I}


ISSN: 2362-1303 (Paper) | eISSN: 2362-1311 (Online)

JOURNAL OF ADVANCED ACADEMIC RESEARCH (JAAR)

June 2020

Table 6: Final table on descriptive analysis of Management system

\begin{tabular}{|c|c|c|c|c|c|c|c|c|}
\hline & & & & & & & \multicolumn{2}{|c|}{$\mathrm{n}=377$} \\
\hline Variables & $\begin{array}{c}\text { Number } \\
\text { of } \\
\text { indicator }\end{array}$ & Mean & S D & $\begin{array}{l}\text { Std } \\
\text { error }\end{array}$ & $\begin{array}{l}\text { Lower } \\
\text { bound }\end{array}$ & $\begin{array}{l}\text { Upper } \\
\text { bound }\end{array}$ & $\begin{array}{l}\text { Mini } \\
\text { mum }\end{array}$ & $\begin{array}{l}\text { Maxi } \\
\text { mum }\end{array}$ \\
\hline $\begin{array}{l}\text { Institutional } \\
\text { management }\end{array}$ & 17 & 59.6 & 3.7 & $\overline{0.18}$ & 59.27 & 60.01 & 43 & 65 \\
\hline $\begin{array}{l}\text { Academic } \\
\text { management }\end{array}$ & 36 & 139.8 & 6.2 & 0.32 & 139.18 & 140.45 & 103 & 151 \\
\hline $\begin{array}{l}\text { Human resources } \\
\text { management }\end{array}$ & 13 & 43.5 & 2.8 & 0.14 & 43.25 & 43.82 & 32 & 52 \\
\hline $\begin{array}{l}\text { Physical resource } \\
\text { management }\end{array}$ & 12 & 45 & 3.1 & 0.18 & 44.71 & 45.33 & 31 & 49 \\
\hline
\end{tabular}

Above Table 6 shows that, in institutional management the minimum score is 43 and maximum 65(mean59.6, SD \pm 3.7 ). In academic management minimum score 103 and maximum score 151(mean13 9.8, $\mathrm{SD} \pm 6.2$ ). As like human resources management minimum score is 32 and maximum is 52 (mean $43.5 \mathrm{SD} \pm 2.8$ ). In physical resources management (mean $45, \mathrm{SD} \pm 3.1$ ) is found 


\section{Table 7: Analysis of variance (ANOVA) on Management system}

Table 7 shows that there was statistically significant difference between group (administrators, faculties and students) in management system included institutional, academic, human resources,

\begin{tabular}{|c|c|c|c|c|c|c|}
\hline \multicolumn{2}{|l|}{ Variables } & $\mathrm{N}$ & Mean & $\begin{array}{c}\text { Std. } \\
\text { Deviation }\end{array}$ & value & $\begin{array}{c}\text { Significanc } \\
\mathrm{e}\end{array}$ \\
\hline \multirow{5}{*}{$\begin{array}{l}\text { Institutional } \\
\text { Management }\end{array}$} & Administra & 14 & 80.500 & 4.3633 & 169.139 & 0.000 \\
\hline & tor & & & & & \\
\hline & Faculties & 229 & 62.821 & 5.5265 & & \\
\hline & students & 377 & 59.642 & 3.6680 & & \\
\hline & Total & 620 & 61.287 & 5.5398 & & \\
\hline \multirow{5}{*}{$\begin{array}{l}\text { Academic } \\
\text { Management }\end{array}$} & Administra & 14 & 179.643 & 0.8419 & 3299.498 & 0.000 \\
\hline & tor & & & & & \\
\hline & Faculties & 229 & 174.148 & 2.9860 & & \\
\hline & students & 377 & 139.820 & 6.2266 & & \\
\hline & Total & 620 & 153.398 & 17.7204 & & \\
\hline \multirow[t]{4}{*}{$\begin{array}{l}\text { Human Resource } \\
\text { management }\end{array}$} & $\begin{array}{l}\text { Administra } \\
\text { tor }\end{array}$ & 14 & 58.857 & 2.3157 & 431.509 & 0.000 \\
\hline & Faculties & 229 & 51.345 & 4.5363 & & \\
\hline & students & 377 & 43.541 & 2.7951 & & \\
\hline & Total & 620 & 46.769 & 5.4622 & & \\
\hline \multirow{5}{*}{$\begin{array}{l}\text { Physical Resource } \\
\text { Management }\end{array}$} & Administra & 14 & 58.500 & 2.1394 & 1094.423 & 0.000 \\
\hline & tor & & & & & \\
\hline & Faculties & 229 & 55.607 & 2.2986 & & \\
\hline & students & 377 & 45.027 & 3.0847 & & \\
\hline & Total & 620 & 49.239 & 5.9642 & & \\
\hline
\end{tabular}

and physical resources management, found $(p<.05)$ in the perceptions of students regarding the management of educational institutes.

\section{DISCUSSION}

The aim of the study was to identify the management of nursing education institutes in Nepal. For this purpose the keys indicators of the management were developed on the basis of various literatures. The key indicators consist of 81 items. Each item had 5likert score. Strongly agree (5), agree (4), Undecided (3), disagree (2) and strongly disagree (1). The lowest score that can be obtained from respondent is 81 whereas the highest score is 405 . The major variables were

Vol. 7. No. I

www.phdcentre.edu.np 
institutional management, academic management, human resource management, and physical resources management.

The finding shows that above half of students were bachelors in nursing science (BNS) programme, majority of students were from Kathmandu district, it is due to majority institutes were sampling from Kathmandu district. All most all (94.2\%) students were agreed on the goal of nursing education institute clearly stated. This finding is supported by a study conducted in Kenya show that goals objectives, policies, and methods of organization were largely communicated to teachers, learners and parents, they should understood it clearly(Karanja et.al., 2014).Majority of students were agreed on the goal of nursing education institute stated clearly $(88.1 \%)$. And all of staff understood it. Majority students agreed all staff understood the organization vision, mission and objectives of the organization. Majority of student were agreed on organizational structure is clearly written and displayed. More than one third of students were undecided on executive committee is functioning. This finding is supported by a study conducted by (Ahmed, 2012) where result show that only $26 \%$ students view that management committees is well run and help the institution. Most of the students were agreed on nurse leader provide effective leadership. Success of an organization achieves its objectives, and satisfies social responsibilities as well, depends on its managers. If managers do their jobs well, and organization will probably achieve its goals. The managerial performance is the subject of much debate. This result supported by a study conducted in Islamabad, Pakistan in secondary level student show that $71 \%$ students say that head teacher has good leadership qualities, 87\%, says they take interest in the institutional programmes, have opportunities to discuss class results, encouraged to participate in co-curricular activities, good behavior, takes class, provide learning facilities (Ahmed, 2012). All most all (95.9\%) students were agreed on the separated administration section (financial, personnel, Examination) exist in NEI. Only 46.7\% students were agreed on resource sufficient to operate the institute. All most all students were undecided on quality assurance system used in institute. But in contrast a study result show that head teachers should take up their roles as quality assurance officers in their schools and ensure that there is adequate supervision. They should frequently invite quality assurance officers to advice on school affairs and community relations (Mobegi et.al., 2010).it may due to in different setting.

In Academic management more than half students agreed on the proper teacher students' ratio for theory and practical but in a study conducted in secondary school in Pakistan found 27\% students say that number of teachers is sufficient in their school, this may be differences of education programme, setting and sample size that was conducted only in 40 students (Ahmed, A. 2012).All most all of student agreed on their faculties are competent in teaching theory as well as practical it also supported study conducted in Kenya found that the most teachers used appropriate teaching/learning resources they were competent in subject matter, students perceived the educational institution as having model teachers (Karanja, 2014).In a case study, Lewis (2010) 
found that the nursing students described a supportive environment for learning, teaching methods, curriculum design, and previous academic success and learning abilities as facilitators of learning help learning. This finding also supported by a study conducted in India, where the perception of students in learning falls in the range of scores 2-3, which is good. A problem-based approach for teaching and evaluation may be a solution. Students' perception of teachers' domain's mean score was 26.95 (5.07), which is in the range of 'more positive. This shows the confidence they have in the teachers because of their rich teaching content and method of teaching (Amaranathan et.al., 2018). Scarboro (2012) conducted a study on "student perception on good teaching" in Istanbul finding showed that several variables were significant relationships to the perception of the faculty as effective teachers. They include faculty helpful in their offices $(B=.184, p<.001)$, GPA $(B=$ $.089, \mathrm{p}<.012)$, and the presence of foreign students enhances learning $(B=.068, p<.05) .77 \%$ of the respondents agreed that their faculty were "very effective in helping [them] understand the subjects [they are] studying," students perceived that faculty who were active in their research, helpful in their offices, homework as the most important factors supporting their learning. It is worthy of note (Scarboro, 2012).In a study conducted by (Hakimzadeh, 2013) found that students' perceptions of the curriculum, including content, teaching methods and assessment, consider as a factor that affects learning and will eventually lead to competence of their learning.(Ahmed, 2012) study found that $(66 \%)$ students vied positive towards institution management they view that institution preparing them for the future. All most all students agreed on definite plan for student intake in the institute. All most all students agreed on they achieved skill, knowledge as curriculum indicated. This finding supported to study conducted (Barami and Belgan, 2003) in their research; perception of learning was directly related to clinical competence, student get adequate learning skills. Majority of the students agreed nursing education institutes apply the evaluation policy provided by respected university. Majority students agreed institutes provided the education programme on the base of operation plan. Most of all students agree on they get equal opportunity to learn. Only $69.8 \%$ students were agreed they got effective supervision a descriptive study on undergraduates or graduates have mentioned that effective clinical teaching, quality of clinical supervision, is success and learning of students, they had positive perception towards clinical supervision (Barami and Belgan, 2003).

Most of students agreed the budget releasing timely for programme implementation. Above half of students agreed on financial activities are transparent of the institute. Majority students agreed on salary of the staff were similar to other same type of job. Student perception towards financial management found that Head teachers should devise school income generating activities to alleviate current financial problems and management financial properly(Mobegi, Ondigi and Oburu, 2010). Lingren and Althin (2010) conducted a study entitled "nurse lecturers' perceptions of what baccalaureate nursing students could gain from clinical group supervision". Their study showed that the nurse teachers felt that their students had become aware of their own strengths and 
weaknesses by clarifying their thoughts in the session; also, they felt that the supervision sessions could increase the students' personal and professional strength by widening their understanding both cognitively and emotionally. Their findings have shown that the students' awareness of the theory practice gap and the necessity to continue searching for new knowledge was considered to increase during the supervision program; also, the students' self-esteem and self-confidence could be strengthened through the confirmation and acknowledgment they received from the supervisor Above-mentioned studies demonstrate the positive effect of clinical supervision instruction process based on both teachers and students view point. Kristofferzon et al in a study done in 2013 have revealed that nursing students seemed to be satisfied with clinical supervision provided by preceptors, teachers, and clinical instructors. Also, they stated that the supervision provided by the group of facilitators helped the students to fulfill their learning outcomes to a large extent.

Majority (78.2\%) students agreed that all staff had written job description. More than half (58.4\%) of students agreed nursing administrator had definite authority and accountability related to nursing programme and $76.7 \%$ students were agreed they are upgraded in own organization. Only $40.6 \%$ students agreed that personnel were recruited through open competition. Below half of the students agreed on personnel were evaluated annually. Majority students agreed NEI provide training to the staff for their professional development as needed and they were satisfied with their job. Similar result found in a study where majority of respondents agreed that students, teachers and non-teaching staff were involved in decision making process. Student representatives were allowed in almost all schools to represent their interests.96\% students were strongly agreed, the school performance stopped student dropout. There were well laid out policies, goals and objectives and methods of achieving them; they were largely communicated to teachers, learners and parents. Most teachers used appropriate teaching/learning resources. While more than $70 \%$ of schools organized social interaction platforms, activities and meetings. In about $60 \%$ of schools, teachers and non-teaching staff were offered promotional and training opportunities or encouraged to pursue them (Betty, 2014).

All most all (above 90\%) students agree on collage building can fulfilled the academic requirement of the institutes, class rooms are sufficient and well equipped and Nursing Education Institutes had their own general hospital for clinical practice. 68.4\% students agreed the skill laboratory are well equipped and they can use the lab. Majority students agreed library fulfilled the student academic need. $87 \%$ students agreed NIE provide computer and internet facility for the students as well as staff. Only $74.5 \%$ students agreed the transportation facility provided by NEI for them. A study conducted in India asserts that the physical facilities do influence the overall students' perceived service quality because students will associate various tangible elements with the services provided by the higher education institution. Furthermore, it can be interpreted that the respondents of Standalone institutions are satisfied with all Institution factors. This is evident from the fact that $\mathrm{t}$-statistics is insignificant $(\mathrm{t}=<1.96 \mathrm{Sig}>.05)$ for all institution factors that there is no 
significant difference between the expected mean scores and perceived mean scores of respondents with respect to, academics, infrastructure, cost and personnel (Ravindrana, 2012). Students' performance is significantly correlated with satisfaction with academic environment and the facilities of library, computer lab and etc. in the institution. With regard to background variables, he found a positive effect of high school performance and school achievement (Kerry \& Paulinen, 2011). Student performances are linked with use of library. The use of the library positively affected the student performance. The academic environment is the effective variable for students has positive relationship grade level (Kirmani \& Siddiquah, 2008).

\section{CONCLUSION}

Study findings indicated that majority of students were agree and strongly agree in management system of the nursing education institutes. The level satisfaction found high in academic management. In statistical analysis show the significance. So it is concluded the perception of students were significantly different in management system of nursing education institutes.

\section{REFERENCES}

Amaranathan, A., Dharanipragada, K., \&Lakshminarayanan, S.(2018) Medical students' perception of the educational environment in a tertiary care teaching hospital in India. The national medical journal of India vol. 31, no. 4,

Ahamad, A. (2011). An urge for quality and quality assurance of basic nurse education, Pakistan: the leadership perspective. International journal of collaborative research on internal medicine \& public health.vol 13,(9), Sept 2011. (Available in http://www.iomcworld.com/ijcrimph/

Aziz, A. (2011). An urge for quality and quality assurance of basic nurse education, Pakistan: the leadership perspective. International journal of collaborative research on internal medicine \& public health.vol 13,(9), Sept 2011. (Available in http://www.iomcworld.com/ijcrimph/

Clement, I (2016). Management of Nursing Service and Education. Ed: $2^{\text {nd }}$. Publisher: ELSEVIER. ISBN: 9788131239919

Barami , J ., \&Blegen , M. A. (2003). New graduate perception of clinical competence: testing a causal model. International Journal of Nursing studies, 40(2003), 389-399

Ravindrana, S., M.K. (2012). Students' Expectation, Perception and Satisfaction towards the Management Educational Institutions. 2nd Annual International Conference on Accounting and Finance (AF 2012). Procedia Economics and Finance 2, $401-410$ 
Hanif N., Parvizy S. andJoolaee S. (2012). Nursing challenges in motivating nursing students through clinical education: a grounded theory study. Nursing research and practice vol(2012)DOI10.1155/2012/161359

Hattingh, S. (2003). The ABC of the NQF. Pretoria: eGEDI.(www.learningroadmap. Co.za). Huma, Z. (2005).Analytical Assessment of Management Styles of Principals on Blake and Mouton's Grid. Ph.D thesis, University Institute of Education and Research, University of Arid Agriculture, Rawalpindi, Pakistan. P.1, 12, 15

Karanja, B. W., Gikungu, J. M., Wagithunu, M. N.,(2014). Effectiveness of Management Theories in Learning Institutions in Kenya. Mediterranean Journal of Social Sciences MCSER Publishing, Rome-Italy Vol 5 No 5. Doi:10.5901/mjss.2014.v5n5p

Kerry R. L. \& Sampson, Paulinen M. (2011). School board member professional development and effect on student achievement. International Journal of Educational Management, vol.25, N0.7, pp.701-713.

Kirmani, Neghat Sana \&Siddiquah, Aishah(2008). Identification and Analysis of Factors Affecting Students Achievement in Higher Education.2nd International Conference on assessing quality in higher education.

Mobegi, 0.,Ondigi, B.,\&Oburu, O. (2010). Secondary school head teachers' quality assurance strategies and challenges in Gucha district, Kenya. Education Research and Reviews Vol. 5(7), pp. 408-414.

Scarboro, A. (2012). Student perception of good teaching. International Journal of New Trends in Arts, Sports \& Science Education, volume 1 Issue 1. Fatih University, Turkey.

Williams, RP. (2012). Nurse leaders' perceptions of quality nursing: an analysis from academy. Nursing Outlook 46(1):262-267.

Lindgren B, Athlin E.(2010). Nurse lecturers' perceptions ofwhat baccalaureate nursing students could gain fromclinical group supervision. Nurse Education Today.; 30:360-4.

Kristofferzon ML, Mårtensson G, Mamhidir AG,LöfmarkA(2013). Nursing students' perceptions of clinicalsupervision: The contributions of preceptors, headpreceptors and clinical lecturers.Nurse EducationToday.;33: 1252-7.). 